\title{
Postural stability in girls with idiopathic scoliosis
}

\author{
M Wiernicka, Thomasz Kotwicki ${ }^{*}$ D Kaczmarek, D Lochynski \\ From 7th International Conference on Conservative Management of Spinal Deformities \\ Montreal, Canada. 20-22 May 2010
}

\section{Introduction}

Idiopathic scoliosis (IS) may be related to decreased postural control of the body. The aim of the study was to investigate the postural control in a group of IS girls compared with healthy girls.

\section{Material}

Eighteen IS girls, aged 12-14 years, mean $13.2 \pm 0.8$, mean height $157.4 \pm 7.0 \mathrm{~cm}$, mean weight $47.0 \pm 9.4 \mathrm{~kg}$, mean BMI $18.7 \pm 3.0$ and seventeen healthy controls aged $12-14$, mean $13.2 \pm 0.9$, mean height $158.5 \pm 7.6$, mean weight 50.2 $\pm 11,6$, mean BMI 19.8 \pm 3.7 were examined. The Cobb angle varied from 20 to 90 degrees, mean $39.1 \pm 16.9$ degrees.

\section{Methods}

Standing balance was tested with CQ-STAB force platform: sway pathway $(\mathrm{mm})$, area $\left(\mathrm{mm}^{2}\right)$ of the centre of pressure (COP) were measured within the left and the right leg. Dynamic balance with two-leg standing on equilibrium board was studied with DELOS Postural System: platform frontal sway from the horizontal axis $\left({ }^{\circ}\right)$ and trunk frontal and sagittal sway from the vertical axis $\left({ }^{\circ}\right)$. Both static and dynamic examination was performed with eyes open (EO) and with eyes closed (EC). Each condition was tested three times, with the subject given a 2-minute resting period between tests and the best performance was used for statistical analysis.

\section{Results}

All studied parameters reveled higher values when performed with EC than with EO in both groups. No differences of measured parameters performed with EC between groups were found. With EO, the IS group revealed higher values of sway pathway in frontal plane and sway area when standing on a right leg and sway pathway when standing on a left leg.

University of Medical Sciences, Poznan, Poland

Full list of author information is available at the end of the article

\section{Discussion}

Small number of subjects in each group is the limitation of the study, however the inclusion of curves being currently within the period of progression is the strong part of it.

\section{Conclusions}

The control of postural stability in girls with IS, being within the period of progression, seems as good as in healthy girls. It was slightly disturbed only on static examination with eyes open.

Published: 10 September 2010

doi:10.1186/1748-7161-5-S1-036

Cite this article as: Wiernicka et al:: Postural stability in girls with idiopathic scoliosis. Scoliosis 2010 5(Suppl 1):036.
Submit your next manuscript to BioMed Central and take full advantage of:

- Convenient online submission

- Thorough peer review

- No space constraints or color figure charges

- Immediate publication on acceptance

- Inclusion in PubMed, CAS, Scopus and Google Scholar

- Research which is freely available for redistribution

Submit your manuscript at www.biomedcentral.com/submit
O) Biomed Central 